\title{
Photocatalysis with the Use of ZnO Nanostructures as a Method for the Purification of Aquatic Environments from Dyes
}

\author{
A. M. Kasumov ${ }^{a, *}$, K. A. Korotkov ${ }^{a}$, V. M. Karavaeva ${ }^{a}$, M. M. Zahornyi ${ }^{a}$, \\ A. I. Dmitriev ${ }^{a}$, and A. I. Ievtushenko ${ }^{a}$ \\ ${ }^{a}$ Frantsevich Institute for Problems of Materials Science, National Academy of Sciences of Ukraine, 03680 Kyiv Ukraine \\ *kasumov@ipms.kiev.ua
}

Received October 15, 2020; revised February 22, 2021; accepted April 29, 2021

\begin{abstract}
The papers devoted to the purification of aquatic environments from industrial contaminants with the use of $\mathrm{ZnO}$ based nanosized photocatalysts in the period of 2018-2020 are analyzed. The data published in these papers have made it possible to determine the dye $(V)$ destruction rate used further as a photocatalytic activity criterion. As shown by the comparative analysis of the photocatalytic activity of the studies structures, the highest rates of water purification from industrial azodye contaminants are demonstrated by hybrid $\mathrm{ZnO} / \mathrm{Au}$ structures. At a destruction rate of $V=10 \% / \mathrm{min}$, the $\mathrm{ZnO} / \mathrm{Au}$ structures are much better than all the other considered types of catalysts due to their morphology, low recombination rate of photogenerated electron-hole pairs, and nanoparticles with an absorption spectrum close to the solar spectrum. The review of literature data shows that the greatest attention of researchers in the considered time period is focused on the problem of the purification of water sources from industrial contaminants and, first of all, azodyes. Essential attention is also paid to the technological approaches applied by the authors to increase the photocatalytic activity of $\mathrm{ZnO}$ based nanostructures.
\end{abstract}

Key words: azodyes, zinc oxide, waste water, photocatalysis, destruction rate

DOI: $10.3103 / \mathrm{S} 1063455 \mathrm{X} 21040044$

\section{INTRODUCTION}

Zinc oxide is a broadband direct-gap semiconductor material with a bandgap width $E_{\mathrm{g}}$ of $3.37 \mathrm{eV}$ at room temperature. Due to an advantageous combination of chemical inertness, transparency, low cost, manufacturability, and unique multifunctional properties, $\mathrm{ZnO}$ attracts the interest of researchers in the field of physics, material science, chemistry, biochemistry, and other sciences [1]. The study of $\mathrm{ZnO}$ based nanostructures is promising and important due to new opportunities of their application for the creation of light diodes, gas sensors, field-emission transistors, ultraviolet lasers, solar-energy photoconverters, and efficient photocatalytic materials [2, 3]. It is known that the doping of $\mathrm{ZnO}$ with accepting impurities ( $\mathrm{Li}, \mathrm{Na}, \mathrm{K}, \mathrm{N}, \mathrm{P}, \mathrm{As}, \mathrm{Sb}, \mathrm{Cu}$, and some other elements) is studied to switch the electron type of conductivity in zinc oxide for hole conductivity [4]. Donating impurities (Al, Ga, In, etc.) are added to the zinc oxide lattice to reduce its specific resistance, and the doping with rare-earth elements is performed to change its optical absorption spectrum [5]. The doping of $\mathrm{ZnO}$ with nitrogen is used to improve the photoelectric properties of $\mathrm{ZnO}$ based $\mathrm{UV}$ detectors [6,7]. $\mathrm{ZnO}$ is also doped with noble metals $(\mathrm{Ag}, \mathrm{Au}, \mathrm{Pd}$, $\mathrm{Pt}$ ) [8] to increase the intensity of photoluminescence and improve the photocatalytic activity due to the implementation of surface plasmon resonance [4].

At the present time, the photocatalytic properties of nanosized $\mathrm{ZnO}$ based structures are investigated along a wide front of studies, which open opportunities for the application of this material for the solution of such global-scale problems as air and water purification from contaminants and pathogenic microorganisms. Some detailed reviews of the papers devoted to the problems of photocatalysis with the use of $\mathrm{ZnO}$ based nanostructures are given in [9-11]. In these papers, the methods for the synthesis and modification of $\mathrm{ZnO}$ nanoparticles are considered alongside with catalysis mechanisms, and $\mathrm{ZnO}$ application prospects are estimated. In the present review, the papers devoted to studying the process of photocatalysis with $\mathrm{ZnO}$ nanostructures in the period of 2018-2020 are analyzed. The results obtained during the photocatalytic purification of water from contaminants with the use of different modification of $\mathrm{ZnO}$ nano- 
structures are compared, and the problems facing the researchers of photocatalytic processes in the future are defined.

The contamination of natural water basins is an essential problem all over the planet. The most hazardous contaminants are complex compounds undegradable under natural conditions. Among them are azodyes, which amount up to a half of the industrial production of dyes [12]. Such dyes are widely applied in textile, printing, leather, coating, paper, rubber, plastic production industry. It has been proven that $15-$ $20 \%$ of such dyes get into waste water in the process of their application and have a cancerogenic and mutagenic effect on living organisms [13].

The most efficient method for the purification of waste water from contaminants over this time period is heterogeneous photocatalysis, which is based on the principles of nanotechnologies and can remove a broad spectrum of organic compounds at a high rate under the influence of a renewable energy source, such as solar radiation $[9,10]$. The comparative analysis of the photocatalytic activity of different nanocatalysts has shown the efficiency of $\mathrm{ZnO}$ based materials [11].

\section{PHOTOCATALYTIC ACTIVITY ESTIMATION METHOD}

The photocatalytic destruction of organic contaminants on nanoparticles of an oxide semiconductor catalyst is described in [14]. The efficiency of this process depends on the properties of nanoparticles, such as their size, shape, crystallinity, crystal lattice type, doping impurities, and the method used for the deposition of nanoparticles on a substrate $[9,10]$. These parameters influence the optical absorption of light,

the recombination rate of electron-hole pairs, and the efficiency of the formation of ${ }^{\circ} \mathrm{OH}$ and ${ }^{\prime} \mathrm{O}_{2}^{-}$radicals. Hence, the photocatalytic activity of nanoparticles is determined by the technology of their creation. The traditional techniques used for the synthesis of $\mathrm{ZnO}$ nanostructures are precipitation, coprecipitation, colloid methods, the sol-gel method, the water-oil method of microemulsions, hydrothermal synthesis, and also the solvothermal, sonochemical, and polyol methods. Some specific features inherent in the new supercritical antisolvent (SAS) precipitation method [13], which is an environmentally friendly technique based on the use of arabinose, a natural monosaccharide, have been recently demonstrated [15]. The studies on the properties of $\mathrm{ZnO}$ based nanostructures are aimed at searching for the ways of improving their catalytic activity, which cause the efficiency of their practical application.

In all the considered papers, photocatalytic activity was estimated by calculating the degree of destruction $D$ determined as the dye concentration change for the reaction time $t$ as

$$
D=\frac{C_{0}-C_{t}}{C_{0}} \times 100
$$

where $C_{0}$ and $C_{t}$ are the initial and residual dye concentrations, \%, respectively.

Since the reaction time $t$ is specified in different ways, we used the destruction rate $v$ representing the average relative change in the dye concentration per $1 \mathrm{~min}$

$$
v=\frac{C_{0}-C_{t}}{C_{0}} \times 100 \frac{1}{t}
$$

as a criterion of objective comparison between the efficiencies of different catalytic activity improvement technologies.

\section{PHOTOCATALYTIC ACTIVITY OF ZnO BASED NANOSTRUCTURES}

The highest photocatalytic activity at $v=10.00 \% / \mathrm{min}$ was attained in $\mathrm{ZnO} / \mathrm{Au}$ nanostructures [16]. These nanostructures were synthesized by the coprecipitation of $\mathrm{ZnO}$ and $\mathrm{Au}$ from hydrogen tetrachloroaurate(III) $\left(\mathrm{HAuCl}_{4} \cdot 3 \mathrm{H}_{2} \mathrm{O}\right)$, zinc nitrate $\left(\mathrm{Zn}\left(\mathrm{NO}_{3}\right)_{2} \cdot 6 \mathrm{H}_{2} \mathrm{O}\right)$, and $\mathrm{KOH}$ solutions. Au nanoparticles were included into a $\mathrm{ZnO}$ matrix. The morphology of $\mathrm{ZnO} / \mathrm{Au}$ nanostructures was transformed with an increase in the Au concentration from nanowires to marigold-shaped flower-like structures. The absorption of nanostructures was observed to intensify in the visible spectral region $(450-650 \mathrm{~nm})$ due to the surface plasmon absorption of Au nanoparticles. The coincidence between the wavelength used for irradiation of photocatalysts and the wavelength of plasmon absorption by Au particles $(550 \mathrm{~nm})$ is one of the reasons for the fast oxidative destruction of sulforhodamine $\mathrm{B}$ with an initial concentration of $90.12 \mathrm{mg} / \mathrm{dm}^{3}$ by $\mathrm{ZnO} / \mathrm{Au}$ nanostructures. The dye destruction rate grew with an increase in the Au concentration up to $4 \mathrm{~mol} \%$. Such ab increase in the catalytic activity is provoked by a combination of several favorable circumstances: improved solar light absorption due to Au surface plasmons, a slight increase in 
the bandgap width of $\mathrm{ZnO}$ with reduction of recombination between electron-hole pairs, an enlarged surface area of $\mathrm{ZnO} / \mathrm{Au}$ nanostructures in comparison with undoped $\mathrm{ZnO}$, and Schottky barriers formed at the $\mathrm{Au} / \mathrm{ZnO}$ interface. The use of $\mathrm{ZnO} / \mathrm{Au}$ nanostructures has provided 5-fold dye solution purification impossible for pure $\mathrm{ZnO}$ without efficiency loss.

A high destruction rate $v=3.36 \% / \mathrm{min}$ was demonstrated by spherical $\mathrm{ZnO}$ nanoparticles [15] at a radiation wavelength $\lambda=254 \mathrm{~nm}$ (irradiation with an UF-S bactericidal lamp)

And an initial dye concentration of $11 \mathrm{mg} / \mathrm{dm}^{3}$. The particles were synthesized by the simple and environmentally friendly method of mixing aqueous zinc nitrate $\mathrm{Zn}\left(\mathrm{NO}_{3}\right)_{2}$ solutions with arabinose and further heating, evaporation, and calcination of reaction products at different temperatures. The nanoparticles had a hexagonal wurtzite structure. The size of crystals grew with an increase in the temperature from 400 to $700^{\circ} \mathrm{C}$. Here, the absorption edge of $\mathrm{ZnO}$ nanoparticles shifted from $371 \mathrm{~nm}\left(400^{\circ} \mathrm{C}\right)$ to $381 \mathrm{~nm}$ $\left(700^{\circ} \mathrm{C}\right)$ due to the formation of oxygen vacancies. A decrease in $E_{\mathrm{g}}$ from 3.20 to $3.16 \mathrm{eV}$ also occurred. The photocatalytic activity of $\mathrm{ZnO}$ nanoparticles was estimated from the degree of mixture destruction in water with three dyes, such as methyl orange (MO), indigocarmine, and malachite green (MG). Decoloration in the aqueous solution of these dyes was monitored at $\lambda=616 \mathrm{~nm}$. Spherical nanoparticles demonstrated the ability to provide the degree of destruction in the mixture of dyes at a level of $84 \%$ for 25 min of exposure.

High destruction rates $v=3.33 \% / \mathrm{min}$ were also attained for the hybrid $\mathrm{ZnO} / \mathrm{Ag}$ nanostructures [17]. The synthesis of $\mathrm{ZnO}$ particles for these structures was performed by the method of an arc discharge in water between zinc rods. They were further bonded with $\mathrm{Ag}$ via the chemical reduction of salt $\mathrm{AgNO}_{3}$ in the presence of trisodium citrate. In these nanostructures, $\mathrm{ZnO}$ particles had a hexagonal wurtzite structure, and $\mathrm{Ag}$ particles had a face-centered cubic structure. As compared to pure $\mathrm{ZnO}$, the absorption edge of hybrid $\mathrm{ZnO} / \mathrm{Ag}$ structures shifted towards the visible spectral region due to the plasmon effect in $\mathrm{Ag}$ and the presence of defects in $\mathrm{ZnO}$, which were promotive for more efficient absorption of visible light. $\mathrm{ZnO}$ defects in these nanostructures acted as electron traps, which hindered the recombination of electronhole pairs. The combination of these factors in $\mathrm{ZnO} / \mathrm{Ag}$ nanostructures provided an essential photocatalytic activity during the destruction of methylene blue (MB) at a level of $\sim 100 \%$ for $30 \mathrm{~min}$ of insolation. The surface oxidation of these nanostructures led to the formation of $\mathrm{Ag}_{2} \mathrm{O}$ and an increase in the time of total destruction to $120 \mathrm{~min}$ of exposure.

A lower values of $v=1.67 \% / \mathrm{min}$ were observed for $\mathrm{ZnO}$ nanopart6icles synthesized via the thermal decomposition of zinc acetate (AcZn) nanoparticles at 300-600 ${ }^{\circ} \mathrm{C}$ [13]. To decrease the size of AcZn particles used as an initial material for $\mathrm{ZnO}$ synthesis, the method of their precipitation in a supercritical antisolvent (SAS) was used. The used supercritical antisolvent was $\mathrm{CO}_{2}$, and dimethylsulfoxide served as a solvent. The fast diffusion of $\mathrm{CO}_{2}$ into the liquid solvent led to oversaturation for dissolved $\mathrm{AcZn}$ and its precipitation in the form of nanoparticles with small sizes of $\sim 54 \mathrm{~nm}$. At the same time, AcZn untreated by the SAS method had much larger sizes of crystals. Zinc oxide obtained via the decomposition of untreated AcZn at $500^{\circ} \mathrm{C}$ had the morphology of irregular tetrapods with an average size of $81 \mathrm{~nm}$, whereas the decomposition of AcZn treated by the SAS method resulted in regular nanoparticles with an average diameter of $65 \mathrm{~nm}$. The size of particles grew with an increase in the calcination temperature due to the phenomenon of their sintering.

$\mathrm{ZnO}$ particles from treated AcZn had a smaller energy bandgap width $E_{\mathrm{g}}$ of $3.07-3.15 \mathrm{eV}$ and a larger specific surface area of 3.3-6 $\mathrm{m}^{2} / \mathrm{g}$ in comparison with $\mathrm{ZnO}$ synthesized from untreated AcZn with $3.17 \mathrm{eV}$ and $5 \mathrm{~m}^{2} / \mathrm{g}$, respectively. This essentially improved the photocatalytic activity of $\mathrm{ZnO}$ nanoparticles synthesized from AcZn treated by the SAS method in comparison with untreated particles. The complete decoloration of crystalline violet dye under UV radiation occurred 60 min for nanoparticles from treated AcZn and 180 min, i.e., was twice slower for nanoparticles from untreated AcZn. An increase in the photocatalysis rate was promoted by the enlargement of the surface area of $\mathrm{ZnO}$ nanoparticles, the faster migration of charge from the volume to the surface in the photocatalyst with a smaller size, and the absence of organic impurities, which are not formed in the SAS technology.

Closer values of $v=1.63 \% / \mathrm{min}$ were obtained for spherical $\mathrm{ZnFe}_{2} \mathrm{O}_{4}$ nanoparticles doped with rare-

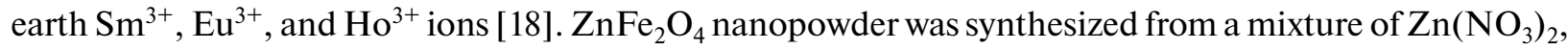
$\mathrm{Fe}\left(\mathrm{NO}_{3}\right)_{2}$, and oxides $\mathrm{Sm}_{2} \mathrm{O}_{3}, \mathrm{Eu}_{2} \mathrm{O}_{3}$, or $\mathrm{Ho}_{2} \mathrm{O}_{3}$ and calcined at $800^{\circ} \mathrm{C}$ for $15 \mathrm{~h} . \mathrm{ZnFe}_{2} \mathrm{O}_{4}$ particles had a cubic crystal lattice with a unit cell parameter $a=8.4 \AA$ and an average particle size within two rages of 50-60 and 90-100 nm. The energy bandgap width of nanoparticles was $2.75 \mathrm{eV}$, being much higher than $1.9 \mathrm{eV}$ typical for massive $\mathrm{ZnFe}_{2} \mathrm{O}_{4}$ samples. Doping with $\mathrm{Sm}^{3+}$ has improved the uniformity of particle sizes, which were ranged within $40-60 \mathrm{~nm}$. No appreciable uniformity of particles has been revealed after 
doping with $\mathrm{Eu}^{3+}$ and $\mathrm{Ho}^{3+}$. After doping $\mathrm{ZnFe}_{2} \mathrm{O}_{4}$ with $\mathrm{Sm}$, Eu, and Ho ions, their $E_{\mathrm{g}}$ shifts from 2.75 to $2.25,2.15$, and $1.7 \mathrm{eV}$, respectively, in agreement with the change in crystallite sizes. The degree of $\mathrm{MG}$ dye destruction during the irradiation of $\mathrm{ZnFe}_{2} \mathrm{O}_{4}$ nanoparticles with visible light is $98 \%$ for 60 min of exposure. The possibility of repeated use was pointed out for this catalyst.

For the $\mathrm{ZnO} / \mathrm{Ag}$ and $\mathrm{ZnO} / \mathrm{Co}$ nanostructures, the obtained values of $v$ are 1.63 and $1.00 \% / \mathrm{min}$, respectively [19]. The $\mathrm{ZnO} / \mathrm{Ag}$ and $\mathrm{ZnO} / \mathrm{Co}$ structures were synthesized as follows. At first, $\mathrm{NaOH}$ was added to the mixture of dissolved salts $\mathrm{Zn}\left(\mathrm{CH}_{3} \mathrm{COO}\right)_{2} \cdot 2 \mathrm{H}_{2} \mathrm{O}, \mathrm{CH}_{3} \mathrm{COOAg}$, or $\mathrm{Co}\left(\mathrm{CH}_{3} \mathrm{COO}\right)_{2} \cdot 4 \mathrm{H}_{2} \mathrm{O}$ in ethanol. The colloid dispersions formed as a result of reaction by $\mathrm{ZnO} / \mathrm{Ag}$ and $\mathrm{ZnO} / \mathrm{C}$ nanoparticles were evaporated at $275^{\circ} \mathrm{C}$ for $1 \mathrm{~h}$. The structure of $\mathrm{ZnO}$ corresponded to hexagonal wurtzite. The size of formed particles was $17.3 \mathrm{~nm}$ for $\mathrm{ZnO} / \mathrm{Ag}$ and $7.2 \mathrm{~nm}$ for $\mathrm{ZnO} / \mathrm{Co}$. The energy bandgap width of $\mathrm{ZnO}, \mathrm{ZnO} / \mathrm{Ag}$, and $\mathrm{ZnO} / \mathrm{Co}$ was $3.47,3.18$, and $3.42 \mathrm{eV}$, respectively. A decrease in $E_{\mathrm{g}}$ for $\mathrm{ZnO} / \mathrm{Ag}$ in comparison with pure $\mathrm{ZnO}$ is explained by surface plasmon resonance in $\mathrm{Ag}$ at $400 \mathrm{~nm}$. The existence of oxygen vacancies on the surface of $\mathrm{ZnO}$ promoted the entrapment of electrons by these traps and reduced the recombination of electron-hole pairs. An increase in the efficiency of photocatalysis was promoted by the existence of $\mathrm{ZnO} / \mathrm{Ag}$ Schottky barriers, which led to the efficient separation of charge carriers in hybrid nanostructures. The listed factors led to an increase in the photocatalytic activity of hybrid nanostructures. The activity of $\mathrm{ZnO} / \mathrm{Ag}$ and $\mathrm{ZnO} / \mathrm{Co}$ was estimated by the degree of destruction for Bismark brown $\mathrm{Y}$ dye under UV radiation for $1 \mathrm{~h}$. The highest degree of dye destruction at a level of $98 \%$ was attained for $\mathrm{ZnO} / \mathrm{Ag}$. A lower activity of $\mathrm{ZnO} / \mathrm{Co}$ structures is due to that the $\mathrm{ZnO}$ energy bandgap contains Co impurity levels, which accelerate the recombination of electron-hole pairs.

In the presence of Co-containing $\mathrm{Zn}_{1-x} \mathrm{Co}_{x} \mathrm{O}$ nanoparticles $(0.0 \leq x \leq 0.1)$, the $\mathrm{MB}$ dye destruction rate $\left(C_{0}=10 \mathrm{mg} / \mathrm{dm}^{3}\right)$ was $V=1.42 \% / \mathrm{min}$ [20]. Co-doped $\mathrm{ZnO}$ nanoparticles were synthesized by a twostage method. At the first stage, the method of coprecipitation from a zinc acetate and cobalt nitrate solution with addition of oxalic acid and ammonium hydroxide was applied. At the second stage, the resulting white precipitate was calcined in the air at $600^{\circ} \mathrm{C}$ for $5 \mathrm{~h}$. The size of $\mathrm{Zn}_{1-x} \mathrm{Co}_{x} \mathrm{O}$ nanoparticles $(0.0 \leq x \leq$ 0.1 ) was $17.4 \mathrm{~nm}$ at $x=0.1$. The particles had a hexagonal wurtzite structure, and the unit cell parameters and size demonstrated the trend to grow with an increase in the parameter $x$. This indicates that $\mathrm{Co}^{2+}$ ions were incorporated into the $\mathrm{ZnO}$ lattice. The doped nanoparticles were more agglomerated than pure $\mathrm{ZnO}$ particles. It has been shown that the concentration of oxygen vacancies grows with an increase in $x$, and impurities may act as electron-hole recombination sites, thereby decreasing the photocatalytic activity of nanoparticles. When $x$ grew from 0 to $0.08, E_{\mathrm{g}}$ decreased from 3.2 to $2.6 \mathrm{eV}$. The doped samples exhibited the trend to ferromagnetism, demonstrating hysteresis loops at room temperature. Photocatalytic activity was estimated from the degree of MB dye destruction $\left(C_{0}=10 \mathrm{mg} / \mathrm{dm}^{3}\right)$ during the irradiation of samples with a xenon lamp. When $x$ grew from 0 to 0.1 , the degree of destruction decreased from 99.3 to $78.8 \%$ for 70 min of irradiation due to the intensification of recombination between electron-hole pairs on the impurity. An increase in the degree of destruction to $99.4 \%$ was demonstrated by the composition with $x=0.04$ alone.

In the study [21], the destruction rate $v=1.27 \% / \mathrm{min}$ was established for undoped $\mathrm{ZnO}$ nanoparticles. The nanoparticles were synthesized from zinc nitrate hexahydrate by the method of flame pyrolysis, in which $\mathrm{O}_{2}$ was used as an oxidizer, and petroleum gas was a fuel. $\mathrm{ZnO}$ particles had a hexagonal crystal structure and were composed of predominantly spherical nanoformations. Photocatalytic activity was estimated by the destruction of amaranth dye at a concentration of $10 \mathrm{mg} / \mathrm{dm}^{3}$ under insolation. Under optimal conditions, the degree of dye destruction was $95 \%$ under insolation for $75 \mathrm{~min}$.

In the study [22], the photocatalytic activity of $\mathrm{ZnO}-\mathrm{Ag} /$ polystyrene (PS) and $\mathrm{ZnO} / \mathrm{PS}$ nanocomposites in the destruction of MB dye under UV radiation was investigated to develop a film photocatalyst, which would float over the surface of an aquatic environment and would not require any essential efforts on its removal from a water basin after use. The $\mathrm{ZnO}-\mathrm{Ag}$ composite was manufactured from a suspension of $\mathrm{ZnO}$ nanoparticles with $\mathrm{AgNO}_{3}$ via the photoprecipitation of $\mathrm{Ag}$ ions onto $\mathrm{ZnO}$ under irradiation with an UV lamp. The reaction product, i.e., the $\mathrm{ZnO}-\mathrm{Ag}$ composite or pure $\mathrm{ZnO}$ nanoparticles, was further mixed with a polystyrene solution in chloroform and dried with the formation of a film, where $\mathrm{ZnO}-\mathrm{Ag}$ or $\mathrm{ZnO}$ were incorporated into a polymer matrix. $\mathrm{ZnO}$ particles had a hexagonal structure of wurtzite. The $\mathrm{ZnO}$ and metallic $\mathrm{Ag}$ phases were sharply separated, and the $\mathrm{Ag}$ amount was $2 \%$ in $\mathrm{ZnO}$. $\mathrm{ZnO}-\mathrm{Ag}$ and $\mathrm{ZnO}$ nanoparticles were strongly agglomerated, and $\mathrm{ZnO}-\mathrm{Ag} / \mathrm{PS}$ and $\mathrm{ZnO} / \mathrm{PS}$ films had high roughness. IR spectra demonstrated the absence of interaction between $\mathrm{ZnO}$ and the functional groups of polystyrene. The presence of $\mathrm{Ag}$ on $\mathrm{ZnO}$ lead to a decrease in the energy bandgap width of this semiconductor from 3.298 to $3.263 \mathrm{eV}$, thus confirming the role of $\mathrm{Ag}$ as a doping impurity. The lifetime of photoinduced electron-hole pairs is also observe to grow due to the transition of electrons from $\mathrm{ZnO}$ to $\mathrm{Ag}$ on the 
Schottky barrier. The degree of MB dye destruction was monitored at a wavelength of $665 \mathrm{~nm}$. During the exposure for $120 \mathrm{~min}$ to UV lamp radiation at attained $v=0.58 \% / \mathrm{min}$, the degree of MB dye destruction was 97 and $70 \%$ for $\mathrm{ZnO}-\mathrm{Ag} / \mathrm{PS}$ and $\mathrm{ZnO} / \mathrm{PS}$, respectively. A rather high destruction rate $v=0.81 \% / \mathrm{min}$ for the $\mathrm{ZnO}-\mathrm{Ag} / \mathrm{PS}$ photocatalyst was explained by the authors by improved conditions for the creation of active oxygen forms in this composite. This film photocatalyst could be used up to three times at a small loss in its efficiency.

The authors [23] attained the MG dye destruction rate $v=0.66 \% / \mathrm{min}$ on $\mathrm{ZnO}$ nanoparticles. In this study, the calcined (annealed) and uncalcined $\mathrm{ZnO}$ forms as photocatalysts of dye destruction in an aquatic environment under UV radiation were compared. The process of calcination-the annealing of $\mathrm{ZnO}$ nanoparticles at $600^{\circ} \mathrm{C}$ for $4 \mathrm{~h}$-led to their recrystallization and agglomeration with the formation of aggregates. Calcined $\mathrm{ZnO}$ particles had high dispersity and a size of up to $25 \mathrm{~nm}$. The degree of destruction for calcined $\mathrm{ZnO}$ was $2 \%$ higher than for uncalcined $\mathrm{ZnO}$ due to an increased amount of nanocrystals formed in the process of annealing. Under optimal photocatalysis conditions, the degree of destruction was $98.48 \%$ for calcined $\mathrm{ZnO}$ and $96.31 \%$ for uncalcined $\mathrm{ZnO}$ at $150 \mathrm{~min}$ of exposure.

$\mathrm{La}_{x} \mathrm{Zn}_{1-x} \mathrm{O}$ nanoparticles, where $x=0.01,0,05$, and 0.10 , have demonstrated the MO dye destruction rate $v=0.57 \% / \mathrm{min}$ [24]. These nanoparticles were synthesized by the combustion of a gel prepared from a $\mathrm{Zn}\left(\mathrm{NO}_{3}\right)_{2} \cdot 4 \mathrm{H}_{2} \mathrm{O}$ and $\mathrm{La}\left(\mathrm{NO}_{3}\right)_{3} \cdot 6 \mathrm{H}_{2} \mathrm{O}$ solution in polyvinyl alcohol. The synthesized samples had a spherical morphology and a particle size, which was inversely proportional to the molar percentage of La and varied from 34.3 to $10.3 \mathrm{~nm}$. The incorporation of La into the $\mathrm{ZnO}$ lattice led to a decrease in $E_{\mathrm{g}}$ from 3.1 to $2.78 \mathrm{eV}$. This argues that $\mathrm{La}_{x} \mathrm{Zn}_{1-x} \mathrm{O}$ is promising for allocation as a photocatalyst for a solution with an initial dye concentration of $10 \mathrm{mg} / \mathrm{dm}^{3}$ under visible light radiation. At $x=0.1$, the degree of MO dye destruction in an aqueous solution was maximal and attained $85.86 \%$ after 150 min of exposure to visible light. The reaction rate constant for the $\mathrm{La}_{x} \mathrm{Zn}_{1-x} \mathrm{O}$ samples with maximum $x=0.1$ was four times higher in comparison with pure $\mathrm{ZnO}$. The authors explain the improvement of photocatalytic characteristics with an increase in the La content by a decrease in the size of nanoparticles, the bandgap width $E_{\mathrm{g}}$, and the rate of recombination between electron-hole pairs.

In the presence of star-shaped $\mathrm{ZnO}$ nanoparticles doped with rare-earth metals $\mathrm{Ce}, \mathrm{La}$, and Ho the photocatalytic decomposition rate of Acid Red 88 dye was $v=0.43 \% / \mathrm{min}$ [25]. The particles were synthesized by the sonochemical method. In this case, a $\mathrm{NaOH}$ solution was added until $\mathrm{pH}$ of 10 to an aqueous $\mathrm{Zn}\left(\mathrm{NO}_{3}\right)_{2} \cdot 4 \mathrm{H}_{2} \mathrm{O}$ and $\mathrm{Ln}\left(\mathrm{NO}_{3}\right)_{3} \cdot 6 \mathrm{H}_{2} \mathrm{O}$ solution, where $\mathrm{Ln}$ is a lanthanide. The mixture was treated with ultrasound for $3 \mathrm{~h}$. The synthesized product was centrifuged, washed, and calcined at $300^{\circ} \mathrm{C}$ for $3 \mathrm{~h}$.

Doped $\mathrm{ZnO}$ particles had a hexagonal structure, a star-shaped morphology without agglomeration, and sizes ranged within $30-50 \mathrm{~nm}$. After doping with Ce, the energy bandgap width $E_{\mathrm{g}}$ decreased from 3.2 to $2.8 \mathrm{eV}$. The Ce impurity has demonstrated the best photocatalytic activity in comparison with La and Ho. Photocatalysis was performed for an aqueous solution of reactive orange 29 dye $\left(C_{0}=10 \mathrm{mg} / \mathrm{dm}^{3}\right)$ under the simultaneous effect of visible light and ultrasound. The combination of sonolysis and photocatalysis accelerated the formation of electron-hole pairs and active oxygen forms, which are necessary for dye destruction. The application of a membrane reactor with polypropylene membranes of hollow fibers combining sonophotocatalysis with filtration by the authors has provided the possibility to increase the degree of destruction of $\mathrm{ZnO} / \mathrm{Ce}$ particles to $97.84 \%$ for $225 \mathrm{~min}$ of exposure.

The low value $v=0.33 \% / \mathrm{min}$ was obtained for nanosized $\mathrm{ZnO} / \mathrm{CO}$ heterostructures [26]. These heterostructures were synthesized from copper acetate $\left(\mathrm{CH}_{3} \mathrm{COO}\right)_{2} \mathrm{Cu}$ and zinc nitrate $\mathrm{Zn}\left(\mathrm{NO}_{3}\right)_{2} \cdot 6 \mathrm{H}_{2} \mathrm{O}$ solutions. Process conditions were created for the formation of first $\mathrm{CuO}$ and then $\mathrm{ZnO}$ or first $\mathrm{ZnO}$ and then $\mathrm{CuO}$. Finer heterostructure particles (of less than $200 \mathrm{~nm}$ ) were synthesized in the first case, and coarser particles $(\sim 400 \mathrm{~nm})$ were formed in the second case. The particles were united into agglomerates of different sizes, which contained both $\mathrm{ZnO}$ and $\mathrm{CuO}$. Te degree of $\mathrm{MO}$ dye destruction under $100 \mathrm{~min}$ of exposure to $\mathrm{UV}$ radiation was 24 and $33 \%$ for $\mathrm{ZnO} / \mathrm{CuO}$ with a particle size of 400 and $200 \mathrm{~nm}$, respectively, which argues for the more advantageous use of finer particles. Under exposure to visible light, the degree of destruction was 12 and 6\%, respectively. In this case, superiority was demonstrated by coarser particles due to a higher $\mathrm{CuO}$ amount on them. The lowest destruction rate $v=0.1 \% / \mathrm{min}$ was obtained for $\mathrm{ZnO}$ nanoparticles and the $\mathrm{ZnO} /$ zeolite composite based on them [27]. This composite was selected to make easier the recovery of the photocatalyst after use in water purification from the food dye tartrazine in comparison with $\mathrm{ZnO}$ nanoparticles. The $\mathrm{ZnO} /$ zeolite composite was synthesized by the chemical precipitation of $\mathrm{ZnO}$ onto clinoptilolite-type zeolite particles from 0.85 to $0.60 \mathrm{~mm}$ in size under boiling in a zinc acetate solution with addition of $\mathrm{NaOH}$ for $2 \mathrm{~h}$. The product precipitate was washed, dried, and calcined at $300^{\circ} \mathrm{C}$. $\mathrm{ZnO}$ nanoparticles were synthesized in a similar way, but without addition of a zeolite material. The structure of both individual $\mathrm{ZnO}$ nanoparticles and $\mathrm{ZnO}$ nanoparticles incorporated into 
the $\mathrm{ZnO} /$ zeolite composite corresponded to the hexagonal wurtzite structure, and the zeolite structure was the same as for the clinoptilolite phase. The average size was $42.7 \mathrm{~nm}$ for both the $\mathrm{ZnO}$ nanoparticles incorporated the composite and individual $\mathrm{ZnO}$ particles. The agglomeration of $\mathrm{ZnO}$ particles in the formation of up to $2-10 \mu \mathrm{m}$ was observed. Such particles had a quasi-spherical shape. The energy bandgap width was $3.20 \mathrm{eV}$ for individual particles and $3.23 \mathrm{eV}$ for the particles incorporated into the $\mathrm{ZnO} /$ zeolite composite, thus arguing for similarity between the mechanisms of photocatalysis in these nanoformations. The degree of tartrazine destruction for $15 \mathrm{~h}$ of exposure to UV radiation was $87 \%$ for $\mathrm{ZnO}$ nanoparticles and $81 \%$ for the composite.

The results of studies on the photocatalytic activity of nanosized $\mathrm{ZnO}$ based structures were considered for the period of 2018-2020. The greatest number of papers was devoted to study of water purification from nitrogen-containing dye contaminants, bactericidal activity [25, 28, 29], and air purification from gaseous impurities of nitrogen oxides like $\mathrm{NO}_{x}$ [30]. The priority of this problem is reflected by the close attention of researchers to the purification of water sources for this period. However, the problem encountered with the pandemic of coronavirus COVID-19, which is generally spread by airborne transmission, allows us to presume that the attention of scientists will be turned soon to the purification of air from microbiological contaminants.

The bactericidal activity in an aquatic environment, as well as the activity in the purification of water from dyes, was highest for the $\mathrm{ZnO} / \mathrm{Au}$ nanocomposite. In other words, the mentioned photocatalytic advantages of the $\mathrm{ZnO} / \mathrm{Au}$ structure were more efficiently exhibited also in the neutralization of microorganisms. This allows us to presume that the $\mathrm{ZnO} / \mathrm{Au}$ composite will also be highly efficient in the purification of air from contaminants.

The use of mathematical modeling in the study [28] for the photocatalytic purification of water from organic and bacterial contaminants opens a qualitatively new period in the investigations of photocatalysis, which will undoubdtly not only be promotive in solving the problems encountered the humanity, but also will increase the level of their solution.

\section{CONCLUSIONS}

Hence, the highest photocatalytic activity was attained in the hybrid $\mathrm{ZnO} / \mathrm{Au}$ and $\mathrm{ZnO} / \mathrm{Ag}$ nanostructures. The advantage of these structures was provided by the combination of two principal factors favorable for photocatalysis, such as the intensive absorption of visible light due to the effect of $\mathrm{Ag}$ and $\mathrm{Au}$ surface plasmons and a decrease in the rate of recombination between electron-hole pairs due to the existence of Schottky barriers. In addition, the coincidence between the absorption maximum of Au surface plasmons and the maximum of solar radiation used in photocatalysis and an extremely developed flowerlike morphology of particles have enabled the $\mathrm{ZnO} / \mathrm{Au}$ structure to attain a record dye destruction rate $(10.0 \% / \mathrm{min})$. It has been shown that the change in the technology used for the manufacturing of hybrid $\mathrm{ZnO} / \mathrm{Au}$ nanostructures has an effect on the surface area of their particles. In the hybrid $\mathrm{ZnO} / \mathrm{CuO}$, $\mathrm{ZnO} / \mathrm{Co}, \mathrm{ZnO} / \mathrm{Ag}_{2} \mathrm{CO}_{3}$, and $\mathrm{ZnO} / \mathrm{Lu}_{3} \mathrm{Al}_{5} \mathrm{O}_{12}$ :Ce heterostructures free from electron-plasmon interaction, the attained destruction rates are low $(1 \% / \mathrm{min})$. The doping of $\mathrm{ZnO}$ with lanthanides $\mathrm{Sm}$, Eu, Ho, $\mathrm{La}_{x} \mathrm{Zn}_{1-x} \mathrm{O}, \mathrm{Ce}, \mathrm{La}$, and $\mathrm{Co}\left(\mathrm{Zn}_{1-x} \mathrm{Co}_{x} \mathrm{O}\right)$, although enabling the use of visible light for photocatalysis, but also leads to low destruction rates $(\leq 1.4 \% / \mathrm{min})$.

Unfortunately, pure $\mathrm{ZnO}$ nanoparticles are active only under UV radiation, but demonstrate a low destruction rate even in this case $(\leq 2.0 \% / \mathrm{min})$.

Hence, it is possible to make a general conclusion that the flower-like $\mathrm{ZnO} / \mathrm{Au}$ nanocomposite catalysts are most efficient for the practical purification of water from contaminants.

\section{FUNDING}

Tis study was performed within the research project of the National Academy of Sciences of Ukraine "Development of Innovative Photocatalytic Nanostructural Materials on the Basis of $\mathrm{ZnO}$ and $\mathrm{TiO}_{2}$ " in the Frantsevich Institute for Problems of Materials Science of the National Academy of Sciences of Ukraine.

\section{REFERENCES}

1. Lashkarev, G.V., Shtepliuk, I.I., Ievtushenko, A.I., Khyzhun, O.Y., Kartuzov, V.V., Ovsiannikova, L.I., et al., Properties of solid solutions, doped film, and nanocomposite structures based on zinc oxide, Low Temp. Phys., 2015, vol. 41, no. 2, pp. 129-140.

https://doi.org/10.1063/1.4908204 
2. Theerthagiri, J., Salla, S., Senthil, R.A., Nithyadharseni, P., Madankumar, A., Arunachalam, P., et al., A review on $\mathrm{ZnO}$ nanostructured materials: Energy, environmental and biological applications, Nanotechnology, 2019, vol. 30, 392001.

https://doi.org/10.1088/1361-6528/ab268a

3. Ievtushenko, A., Tkach, V., Strelchuk, V., Petrosian, L., Kolomys, O., Kutsay, O., et al., Solar explosive evaporation growth of $\mathrm{ZnO}$ nanostructures, Appl. Sci., 2017, vol. 7, no. 4, 383.

https://doi.org/10.3390/app7040383

4. Ievtushenko, A., Karpyna, V., Eriksson, J., Tsiaoussis, I., Shtepliuk, I., Lashkarev, G., et al., Effect of Ag doping on the structural, electrical and optical properties of $\mathrm{ZnO}$ grown by MOCVD at different substrate temperatures, Superlattices Microstruct., 2018, vol. 117, pp. 121-131. https://doi.org/10.1016/j.spmi.2018.03.029

5. Xiu, F., Xu, J., Joshi, P.C., Bridges, C.A., and Parans Paranthaman, M., ZnO doping and defect engineeringA review, in Semiconductor Materials for Solar Photovoltaic Cells, Springer Ser. Mater. Sci., vol. 2018, Cham: Springer, 2016, pp. 105-140.

6. Ievtushenko, A., Khyzhun, O., Shtepliuk, I., Bykov, O., Jakieła, R., Tkach, S., et al., X-ray photoelectron spectroscopy study of highly-doped ZnO:Al, N films grown at O-rich conditions, J. Alloys Compd., 2017, vol. 722, pp. 683-689.

https://doi.org/10.1016/j.jallcom.2017.06.169

7. Ievtushenko, A., Khyzhun, O., Karpyna, V., Bykov, O., Tkach, V., Strelchuk, V., et al., The effect of $\mathrm{Zn}_{3} \mathrm{~N}_{2}$ phase decomposition on the properties of highly-doped ZnO:Al,N films, Thin Solid Films, 2019, vol. 669, pp. 605-612. https://doi.org/10.1016/j.tsf.2018.11.052

8. Liu, H., Feng, J., and Jie, W., A review of noble metal (Pd, Ag, Pt, Au)-zinc oxide nanocomposites: Synthesis, structures and applications, J. Mater Sci.: Mater. Electron., 2017, vol. 28, pp. 16585-16597. https://doi.org/10.1007/s10854-017-7612-0

9. Kezhen, Q., Cheng, B., Yu, J., and Ho, W., Review on the improvement of the photocatalytic and antibacterial activities of ZnO, J. Alloys Compd., 2017, vol. 727, pp. 792-820. https://doi.org/10.1016/j.jallcom.2017.08.142

10. Máynez-Navarro, O.D. and Sánchez-Salas, J.L., Focus on zinc oxide as a photocatalytic material for water treatment, Int. J. Environ. Biorem. Biodegrad., 2018, vol. 106, pp. 1-8. https://doi.org/10.29011/IJBB-106/100006

11. Ong, C.B., Ng, L.Y., and Mohammad, A.W., A review of $\mathrm{ZnO}$ nanoparticles as solar photocatalysts: Synthesis, mechanisms and applications, Renewable Sustainable Energy Rev., 2018, vol. 81, pp. 536-551. https://doi.org/10.1016/j.rser.2017.08.020

12. Azo dye, Chemistry and chemical technology, Handbook of Chemist 21. https://chem21.info/tabmap/.

13. Franco, P., Sacco, O., De Marco, I., and Vaiano, V., Zinc oxide nanoparticles obtained by supercritical antisolvent precipitation for the photocatalytic degradation of crystal violet dye, Catalysts, 2019, vol. 346, no. 9, pp. 115. https://doi.org/10.3390/catal9040346

14. Soboleva, N.M., Nosonovich, A.A., and Goncharuk, V.V., Heterogeneous photocatalysis in water treatment processes, J. Water Chem. Technol., 2007, vol. 29, no. 2, pp. 72-89.

15. Abdulkhair, B.I., Salih, M.E., Elamin, N.Y., Fatima, A.MA., and Modwi, A., Simplistic synthesis and enhanced photocatalytic performance of spherical $\mathrm{ZnO}$ nanoparticles prepared from arabinose solution, Z. Naturforsch., 2019, vol. 74, pp. 1-8. https://doi.org/10.1515/zna-2019-0059

16. Raji, R. and Gopchandran, K.G., Plasmonic photocatalytic activity of ZnO:Au nanostructures: Tailoring the Plasmon absorption and interfacial charge transfer mechanism, J. Hazard. Mater., 2019, vol. 368, pp. 345-357. https://doi.org/10.1016/j.jhazmat.2019.01.052

17. Ziashahabi, A., Prato, M., Dang, Z., and Poursalehi, R., The effect of silver oxidation on the photocatalytic activity of $\mathrm{Ag} / \mathrm{ZnO}$ hybrid plasmonic/metal-oxide nanostructures under visible light and in the dark, Sci. Rep., 2019, vol. 9, 11839 . https://doi.org/10.1038/s41598-019-48075-7

18. Hakimyfard, A. and Mohammadi, $\mathrm{S}$., $\mathrm{ZnFe}_{2} \mathrm{O}_{4}$ and $\mathrm{ZnO}-\mathrm{Zn}_{1-x} M_{x} \mathrm{Fe}_{2} \mathrm{O}_{4+\delta}\left(\mathrm{M}=\mathrm{Sm}^{3+}, \mathrm{Eu}^{3+}\right.$ and $\left.\mathrm{Ho}^{3+}\right)$ : Synthesis, physical properties and high performance visible light induced photocatalytic degradation of malachite green, Adv. Powder Technol., 2019, vol. 30, no. 6, pp. 1257-1268.

https://doi.org/10.1016/j.apt.2019.04.005

19. Martínez-Vargas, B.L., Durón-Torres, S.M., Bahena, D., Peralta-Hernández, J.M., and Picos, A., One-pot synthesis of $\mathrm{ZnO}-\mathrm{Ag}$ and $\mathrm{ZnO}-\mathrm{Co}$ nanohybrid materials for photocatalytic applications, J. Phys. Chem. Solids, 2019, vol. 135, pp. 109-120.

https://doi.org/10.1016/j.jpcs.2019.109120 
20. Pan, H., Zhang, Y., Hu, Y., and Xie, H., Effect of cobalt doping on optical, magnetic and photocatalytic properties of ZnO nanoparticles, Optik, 2020, vol. 208, 1640560. https://doi.org/10.1016/j.ijleo.2020.164560

21. Widiyandari, H., Umiati, N.A.K., and Herdianti, R.D., Synthesis and photocatalytic property of zinc oxide ( $\mathrm{ZnO})$ fine particle using flame spray pyrolysis method, J. Phys.: Conf. Ser., 2018, vol. 1025, 012004. https://doi.org/10.1088/1742-6596/1025/1/012004

22. Naji, H.K., Oda, A.M., Abdulaljeleel, W., Abdilkadhim, H., and Hefdhi, R., ZNO-Ag/PS and ZnO/PS films for photocatalytic degradation of methylene blue, Indones. J. Chem., 2020, vol. 20, pp. 314-323.

23. Chijioke-Okere, M.O., Okorocha, N.J., Anukam, B.N., and Oguzie, E.E., Photocatalytic degradation of a basic dye using zinc oxide, Int. Lett. Chem., Phys. Astron., 2019, vol. 81, pp. 18-26. https://doi.org/10.18052/www.scipress.com/ILCPA.81.18

24. Nguyen, T.T., Nguyen, L.T.H., Duong, A.T.T., Nguyen, B.D., Hai, N.Q., Chu, V.H., et al., Preparation characterization and photocatalytic activity of la-doped zinc oxide nanoparticles, Materials, 2019, vol. 1195, no. 12. https://doi.org/10.3390/ma12081195

25. Sheydaei, M., Fattahi, M., Ghalamchi, L., and Vatanpour, V., Systematic comparison of sono-synthesized $\mathrm{Ce}-$, $\mathrm{La}$ - and Ho-doped $\mathrm{ZnO}$ nanoparticles and using the optimum catalyst in a visible light assisted continuous sono-photocatalytic membrane reactor, Ultrason. Sonochem., 2019, vol. 56, pp. 361-371. https://doi.org/10.1016/j.ultsonch.2019.04.031

26. Levkevich, E.A., Moshnikov, V.A., Yukhnovets, O., and Maximov, A.I., Photocatalytic properties of ZnO/CuO heterostructures, Proc. 2019 IEEE Conf. of Russian Young Researchers in Electrical and Electronic Engineering (EIConRus), Red Hook, NY: Curran Assoc., 2019. https://doi.org/10.1109/EIConRus.2019.8657316

27. Alcantara-Cobos, A., Gutiérrez-Segura, E., Solache-Ríos, M., Amaya-Chávez, A., and Solís-Casados, D.A., Tartrazine removal by $\mathrm{ZnO}$ nanoparticles and a zeolite- $\mathrm{ZnO}$ nanoparticles composite and the phytotoxicity of ZnO nanoparticles, Microporous Mesoporous Mater., 2020, vol. 302, 110212. https://doi.org/10.1016/j.micromeso.2020.110212

28. Murcia, J.J., Hernández, J.S., Rojas, H., Moreno Cascante, J., Sánchez Cid, P., Hidalgo, M.C., et al., Evaluation of $\mathrm{Au}-\mathrm{ZnO}, \mathrm{ZnO} / \mathrm{Ag}_{2} \mathrm{CO}_{3}$ and $\mathrm{Ag}-\mathrm{TiO}_{2}$ as photocatalyst for waste-water treatment, Top. Catal., 2020, no. $11-14 / 2020$. https://doi.org/10.1007/s11244-020-01232-z

29. Jin, S.-E., Jin, J.E., Hwang, W., and Hong, S.W., Photocatalytic antibacterial application of zinc oxide nanoparticles and selfassembled networks under dual UV irradiation for enhanced disinfection, Int. J. Nanomed., 2019, vol. 14, pp. 1737-1751. https://doi.org/10.2147/IJN.S192277

30. Meroni, D., Gasparini, C., Di Michele, A., Ardizzone, S., and Bianchi, C.L., Ultrasound-assisted synthesis of $\mathrm{ZnO}$ photocatalysts for gas phase pollutant remediation: Role of the synthetic parameters and of promotion with $\mathrm{WO}_{3}$, Ultrason. Sonochem., 2020, vol. 55, 105119.

https://doi.org/10.1016/j.ultsonch.2020.105119

Translated by E. Glushachenkova 